\title{
Autoantibodies to speckled protein family in primary biliary cholangitis
}

\author{
Alessandro Granito ${ }^{1,2,3^{*}}$ (D) Luigi Muratori ${ }^{1,2,3}$, Francesco Tovoli ${ }^{1,2,3}$ and Paolo Muratori ${ }^{1,2,4}$
}

\begin{abstract}
The autoantibody profile of primary biliary cholangitis (PBC) includes antinuclear antibodies (ANA) which are detectable by indirect immunofluorescence in more than $50 \%$ of PBC patients. One of the two immunofluorescence patterns which are historically considered "PBC-specific" is the so-called "multiple nuclear dots" (MND) targeting nuclear body proteins such as Sp100, Sp140, Sp140L proteins, promyelocytic leukemia protein (PML) and small ubiquitin-related modifier proteins (SUMO). It has been hypothesized a role of nuclear body protein alterations in immune disorders such as PBC, thus suggesting novel and more refined therapeutic approaches.
\end{abstract}

Keywords: Speckled proteins, Multiple nuclear dots, Antinuclear antibodies, Primary biliary cholangitis

To the editor

Patients with primary biliary cholangitis $(\mathrm{PBC})$ produce antinuclear antibodies (ANA) directed against structural components of promyelocytic leukemia protein (PML) and Sp100-containing nuclear bodies (NBs) [1].

Sp100, PML, Sp140, Sp140L, and small ubiquitinrelated modifier (SUMO) proteins are PML NB-related proteins that are identified as target antigens in $\mathrm{PBC}$ patients [2-6]. These autoantibodies are of clinical relevance in $\mathrm{PBC}$ due to their very high disease specificity and as surrogate markers in anti-mitochondrial antibody (AMA) negative PBC cases (Table 1$)[1,2]$.

Within the spectrum of ANA staining patterns by indirect immunofluorescence, the "multiple nuclear dots" (MND) pattern is therefore historically considered as highly specific for $\mathrm{PBC}[1,7]$.

The MND staining pattern is characterized by the presence of 5-20 dots of variable size distributed throughout the cell nucleus but sparing the nucleoli; it is distinguishable from the centromere staining pattern by the presence of fewer nuclear dots per cell, and by

*Correspondence: alessandro.granito@unibo.it

${ }^{1}$ Division of Internal Medicine, IRCCS Azienda Ospedaliero-Universitaria di Bologna, 40138 Bologna, Italy

Full list of author information is available at the end of the article the absence of dots in cells that are undergoing mitosis (Fig. 1) [7]. The MND staining pattern is also distinct from the anti-p80 coilin/Cajal body staining pattern, which is characterized by the presence of $2-8$ dots per cell nucleus [8].

The mechanism leading to ANA production in PBC is still an unsolved question. It has been suggested that xenobiotics and molecular mimicry between microbial agents and self-antigens might be involved in the triggering of disease as well as in the appearance of autoantibodies $[9,10]$.

Previous data suggest that PML-NBs may have a role in transcriptional events [11]. Moreover, it has been shown that PML, Sp100, and Sp140 are upregulated in response to interferons, a group of proteins with antiviral activities, indicating that PML NBs could also have an important function in antiviral defense [12]. Results from a recent study suggest an implication of Sp140 protein in an innate response to HIV-1 by its interaction with the vif protein encoded by the virus [13].

In their review article, Fraschilla and Jeffrey posit that the speckled protein (SP) family are central chromatin regulators of gene silencing that establish immune cell identity and function [14]. They correctly point out that: (1) mutations in human SP140 associate with three immunological diseases: Crohn's disease, chronic

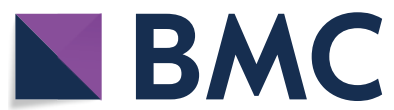

(c) The Author(s) 2021. This article is licensed under a Creative Commons Attribution 4.0 International License, which permits use, sharing, adaptation, distribution and reproduction in any medium or format, as long as you give appropriate credit to the original author(s) and the source, provide a link to the Creative Commons licence, and indicate if changes were made. The images or other third party material in this article are included in the article's Creative Commons licence, unless indicated otherwise in a credit line to the material. If material is not included in the article's Creative Commons licence and your intended use is not permitted by statutory regulation or exceeds the permitted use, you will need to obtain permission directly from the copyright holder. To view a copy of this licence, visit http://creativeco mmons.org/licenses/by/4.0/. The Creative Commons Public Domain Dedication waiver (http://creativecommons.org/publicdomain/ zero/1.0/) applies to the data made available in this article, unless otherwise stated in a credit line to the data. 
Table 1 Relationship between nuclear pore complex proteins, antinuclear antibodies giving the "multiple nuclear dots" immunofluorescence pattern, and clinical significance in patients with primary biliary cholangitis

\begin{tabular}{|c|c|c|c|c|c|}
\hline \multirow[t]{2}{*}{ Nuclear structures } & \multirow[t]{2}{*}{ Indirect immunofluorescence pattern } & \multirow[t]{2}{*}{ Autoantigen targets } & \multicolumn{3}{|c|}{ Autoantibodies in PBC } \\
\hline & & & Prevalence (\%) & Specificity & Worse prognosis \\
\hline \multirow[t]{6}{*}{ Nuclear Bodies } & \multirow[t]{6}{*}{$M N D^{a}$} & Sp100 & $17-41$ & High & To be confirmed \\
\hline & & PML & 19 & High & No \\
\hline & & Sp140 & 15 & High & No \\
\hline & & Sp140L & 1.5 & Not assessed & Not assessed \\
\hline & & SUMO-1 & 15 & Not assessed & Not assessed \\
\hline & & SUMO-2 & 42 & Not assessed & Not assessed \\
\hline
\end{tabular}

Sp100 Sp100 nuclear body component, PML promyelocytic leukemia protein, Sp140 Sp140 nuclear body component, Sp140L Sp140L protein, MND multiple nuclear dots pattern, SUMO small ubiquitin-related modifiers

a MND pattern detected by indirect immunofluorescence using fluorescein-conjugate anti-human total $\lg$ and anti-human $\lg G$ subclasses (lgG1, $\lg 22$, lgG3, lgG4) as secondary antibody was found in $16 \%$ and $31 \%$, respectively $[1,2]$

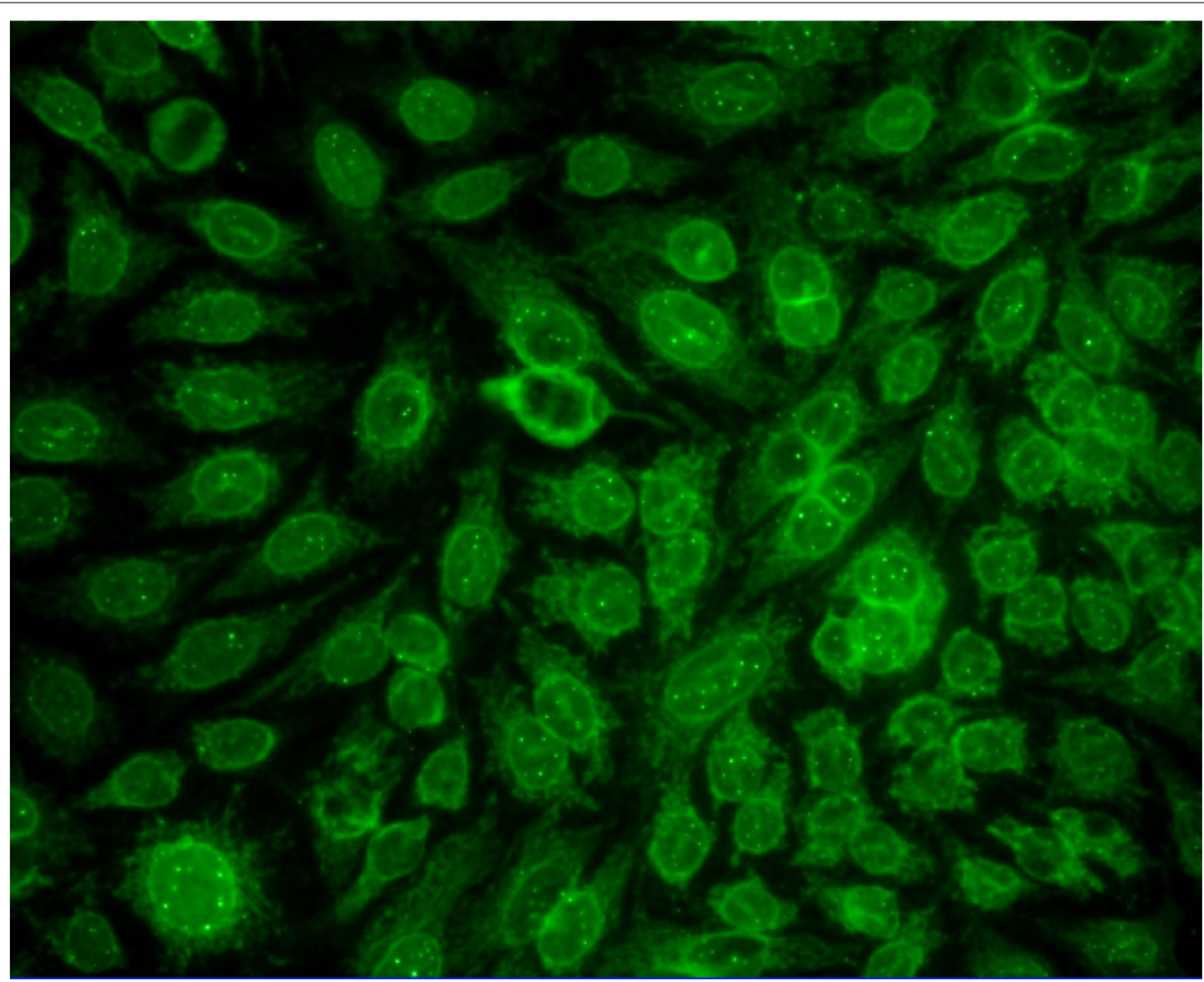

Fig. 1 Multiple nuclear dot staining pattern by indirect immunofluorescence on HEp-2 cells (magnification 20). Anti-multiple nuclear dots react with 3-20 nuclear dots distinct from nucleoli and from the anticentromere targets. Punctate staining of chromosomes in mitosis clearly distinguishes anticentromere from anti-multiple nuclear dots

lymphocytic leukemia, and multiple sclerosis; (2) mutations in human SP110 associate with veno-occlusive disease with immunodeficiency; (3) finally, many viruses have evolved mechanisms to inhibit SP function in PMLNBs, organelles associated with viral gene repression, suggesting that SPs mediate protective viral defense mechanisms [15].

They conclude that all SPs are associated with autoimmune, inflammatory, or infectious diseases, underscoring their role in maintaining immune 
homeostasis and proper functional response to pathogens.

Regarding their role in $\mathrm{PBC}$, it has been widely established the high diagnostic value of autoantibodies direct against SPs, especially in patients lacking antimitochondrial antibodies. Moreover, a prognostic role for MND/anti-Sp100 antibodies has also been suggested: Zuchner et al. described a faster disease progression among anti-Sp100-positive patients with PBC [16]. Rigopoulou et al. reported that anti-MNDpositive patients had significantly more severe liver disease than those that were anti-MND negative, as shown by the higher frequency of cirrhosis and worse outcome [17]. However, these observations still need to be confirmed in larger series of patients, possibly recruited from different centers and with different ethnic and genetic backgrounds.

We would like also to add further relevant and unmentioned evidence that supports a potential role of infections as a potential trigger of PBC and anti-SPs autoantibodies development in genetically predisposed individuals. Specifically, it has been demonstrated a possible role of microorganisms that are responsible for recurrent urinary tract infections, as triggers of $\mathrm{PBC}$ and ANAs generation, has long been suggested [1619]. Moreover, a possible molecular mimicry between the epitopic regions of Escherichia coli and Sp100 has been hypothesized on the basis of a strong correlation between the presence of anti-Sp100 antibodies and AMA positivity in women with recurrent urinary tract infections, with or without evidence of PBC [20].

A different mimicry mechanism has been proposed by Shinoda et al. who have found that peptides from gp210 and Sp100 proteins are recognized by T-cell clones responsive to the major autoepitope of E2 subunit of the pyruvate dehydrogenase complex. The investigators thus hypothesized that the PBCspecific antinuclear reactivities could be the result of intermolecular spreading involving mitochondrial antigens and mimicry sequences of nuclear proteins [21].

It is noteworthy that more than $80 \%$ of anti-NB positive patients has two or three simultaneous anti-NB reactivities, suggesting a "clustering" of autoantigens, an observation supporting the hypothesis that intermolecular epitope-spreading mechanisms might be operative in the propagation of several reactivities in the same patient $[4,22-25]$.

Given the observation that anti-Sp140, as well as anti-PML antibodies, almost exclusively occur in antiSp100-positive patients, but not vice versa, it could be hypothesized that the NB is a multiantigenic complex in which the immune response might involve first Sp100, and only later spread to Sp140 and PML that share the same subnuclear localization.

We agree with Fraschilla and Jeffrey that further studies elucidating mechanisms of SPs alteration, contributing to immune disorders, will aid in the design of new therapies associated with SPs role and function.

Furthermore, immune-expressed SPs may offer novel and more refined therapeutic avenues for taming hyperactive autoimmune responses.

\section{Abbreviations \\ PBC: Primary biliary cholangitis; MND: Multiple nuclear dots; NBs: Nuclear bodies; PML: Promyelocytic leukemia protein; SP: Speckled protein; SUMO: Small ubiquitin-related modifier proteins. \\ Acknowledgements \\ None. \\ Authors' contributions \\ AG and PM reviewed the literature and drafted the manuscript; AG, PM, LM and FT contributed to manuscript drafting; all authors were involved in acquisition of data. All authors read and approved the final manuscript. \\ Funding \\ The authors received no financial support to produce this manuscript. \\ Availability of data and materials \\ Data included in this manuscript are available in the following published manuscripts: \\ 1. Muratori $P$ et al. Autoimmunity. 2009;42:224-7. \\ 2. Granito A et al. Am J Gastroenterol 2010;105:125-31. \\ 3. Granito A et al. Aliment Pharmacol Ther. 2006;24:1575-83.}

\section{Declarations}

Ethics approval and consent to participate

The patients referred to in the manuscript signed a written informed consent form for the purpose of publication of the results and the study was approved by local ethical committee.

\section{Competing interests}

The authors declare that they have no conflicts of interest.

\section{Author details}

${ }^{1}$ Division of Internal Medicine, IRCCS Azienda Ospedaliero-Universitaria di Bologna, 40138 Bologna, Italy. ${ }^{2}$ Center for the Study, Treatment of Autoimmune Diseases of the Liver, Biliary System, Bologna, Italy. ${ }^{3}$ Department of Medical and Surgical Sciences (DIMEC), Alma Mater Studiorum, University of Bologna, Bologna, Italy. ${ }^{4}$ Department for the Science of the Quality of Life (QUVI), Alma Mater Studiorum, University of Bologna, Bologna, Italy.

Received: 7 November 2020 Accepted: 17 March 2021

Published online: 31 March 2021

\section{References}

1. Granito A, Muratori P, Quarneti C, Pappas G, Cicola R, Muratori L. Antinuclear antibodies as ancillary markers in primary biliary cirrhosis. Expert Rev Mol Diagn. 2012;12(1):65-74.

2. Muratori P, Granito A, Ferri S, Pappas G, Volta U, Menichella R, Bianchi FB, Lenzi M, Muratori L. Multiple nuclear dots and rim-like/membranous IgG isotypes in primary biliary cirrhosis. Autoimmunity. 2009;42:224-7. 
3. Bloch DB, Chiche JD, Orth D, de la Monte SM, Rosenzweig A, Bloch KD. Structural and functional heterogeneity of nuclear bodies. Mol Cell Biol. 1999;19(6):4423-30.

4. Granito A, Yang WH, Muratori L, Lim MJ, Nakajima A, Ferri S, Pappas G, Quarneti C, Bianchi FB, Bloch DB, Muratori P. PML nuclear body component Sp140 is a novel autoantigen in primary biliary cirrhosis. Am J Gastroenterol. 2010;105:125-31.

5. Saare M, Hämarik U, Venta R, Panarina M, Zucchelli C, Pihlap M, Remm A, Kisand K, Toots U, Möll K, Salupere R, Musco G, Uibo R, Peterson P. SP140L, an evolutionarily recent member of the SP100 family, is an autoantigen in primary biliary cirrhosis. J Immunol Res. 2015;2015:526518. https://doi. org/10.1155/2015/526518

6. Janka C, Selmi C, Gershwin ME, Will H, Sternsdorf T. Small ubiquitinrelated modifiers: a novel and independent class of autoantigens in primary biliary cirrhosis. Hepatology. 2005;41:609-16

7. Granito A, Muratori P, Muratori L, Pappas G, Cassani F, Worthington J, Guid M, Ferri S, Molo DE, C, Lenzi M, Chapman RW, Bianchi FB. . Antinuclear antibodies giving the 'multiple nuclear dots' or the 'rim-like/membranous' patterns: diagnostic accuracy for primary biliary cirrhosis. Aliment Pharmacol Ther. 2006;24:1575-83.

8. Yang WH, Yu JH, Nakajima A, et al. Do antinuclear antibodies in primary biliary cirrhosis patients identify increased risk for liver failure? Clin Gastroenterol Hepatol. 2004;2:1116-22.

9. Kaplan MM. Novosphingobium aromaticivorans: a potential initiator of primary biliary cirrhosis. Am J Gastroenterol. 2004;99:2147-9.

10. Rieger R, Leung PS, Jeddeloh MR, et al. Identification of 2-nonynoic acid, a cosmetic component, as a potential trigger of primary biliary cirrhosis. J Autoimmun. 2006;27:7-16.

11. LaMorte VJ, Dyck JA, Ochs RL, Evans RM. Localization of nascent RNA and CREB binding protein with the PML-containing nuclear body. Proc Natl Acad Sci USA. 1998:95:4991-6.

12. Regad T, Chelbi-Alix MK. Role and fate of PML nuclear bodies in response to interferon and viral infections. Oncogene. 2001;20:7274-86

13. Madani N, Millette R, Platt EJ, et al. Implication of the lymphocytespecific nuclear body protein Sp140 in an innate response to human immunodeficiency virus type 1. JVirol. 2002;76:11133-8.
14. Fraschilla I, Jeffrey KL. The speckled protein (SP) family: immunity's chromatin readers. Trends Immunol. 2020;41:572-85.

15. Scherer M, Stamminger T. Emerging role of PML nuclear bodies in innate immune signaling. J Virol. 2016;90:5850-4.

16. Züchner D, Sternsdorf T, Szostecki C, et al. Prevalence, kinetics, and therapeutic modulation of autoantibodies against Sp100 and promyelocytic leukemia protein in a large cohort of patients with primary biliary cirrhosis. Hepatology. 1997;26:1123-30.

17. Rigopoulou El, Davies ET, Pares A, et al. Prevalence and clinical significance of isotype specific antinuclear antibodies in primary biliary cirrhosis. Gut. 2005;54:528-32.

18. Bogdanos DP, Baum H, Sharma UC, et al. Antibodies against homologous microbial caseinolytic proteases $P$ characterise primary biliary cirrhosis. J Hepatol. 2002;36:14-21.

19. Selmi C, Gershwin ME. The role of environmental factors in primary biliary cirrhosis. Trends Immunol. 2009:30:415-20.

20. Berg Tanaka A, Leung PSC, Gershwin ME. Pathogen infections and primary biliary cholangitis. Clin Exp Immunol. 2019;195:25-34.

21. Kivity S, Agmon-Levin N, Blank M, Shoenfeld Y. Infections and autoimmunity — friends or foes? Trends Immunol. 2009;30:409-14.

22. Bogdanos DP, Baum H, Butler P, et al. Association between the primary biliary cirrhosis specific anti-sp100 antibodies and recurrent urinary tract infection. Dig Liver Dis. 2003;35:801-5.

23. Shimoda S, Nakamura M, Ishibashi $\mathrm{H}$, et al. Molecular mimicry of mitochondrial and nuclear autoantigens in primary biliary cirrhosis. Gastroenterology. 2003;124:1915-25.

24. James JA, Harley JB. B-cell epitope spreading in autoimmunity. Immunol Rev. 1998;164:185-200.

25. Vanderlugt CL, Miller SD. Epitope spreading in immune-mediated diseases: implications for immunotherapy. Nat Rev Immunol. 2002;2:85-95.

\section{Publisher's Note}

Springer Nature remains neutral with regard to jurisdictional claims in published maps and institutional affiliations.
Ready to submit your research? Choose BMC and benefit from:

- fast, convenient online submission

- thorough peer review by experienced researchers in your field

- rapid publication on acceptance

- support for research data, including large and complex data types

- gold Open Access which fosters wider collaboration and increased citations

- maximum visibility for your research: over $100 \mathrm{M}$ website views per year

At $\mathrm{BMC}$, research is always in progress.

Learn more biomedcentral.com/submissions 